\title{
Analysis of Apparatus Resource Development as an Effort to Improve Performance:A Study of Regional Office of the West Kutai Regency
}

\author{
Suhardiman ${ }^{1}$ \\ ${ }^{1}$ Public administration, Universitas 17 Agustus 1945 Samarinda, Indonesia
}

\begin{abstract}
The purpose of this research is to describe, analyze aspects related to the method of developing apparatus resources in the KutaiKartanegara Regency Regional Secretariat and apparatus performance. This research uses descriptive research method with a qualitative approach. Data collection techniques using in-depth interviews, documentation, and observation. The results showed that the successful implementation of regional autonomy requires apparatus who have the ability, knowledge, and skills as well as behavioral attitudes. Development of apparatus resources must be done with a mechanism or stages so that the objectives of the apparatus and the organization as a whole can be achieved. Development of personnel resources is an important instrument in improving the performance of the apparatus. Implementation of apparatus resource development in the Regional Secretariat of the Regency of KutaiKartanegara in order to improve the performance of the apparatus using the On the Job method and the Off the Job method. Appraisal performance can be seen from aspects of the quantity of work, quality of work, timeliness and knowledge of work, as well as objectives.
\end{abstract}

Keywords: HR development, apparatus, performance

\section{INTRODUCTION}

Development of apparatus resources is very important because it can improve the ability of the apparatus both professional abilities, insight abilities, leadership abilities and the ability to serve so that ultimately it will improve the performance of an apparatus (Zott, 2003). Apparatus that has the ability, knowledge and skills and understands their duties and responsibilities so that the planning of each program can be carried out effectively, efficiently and focused on the objectives to be achieved. The division of tasks of the apparatus is also influenced by the formation of new units with new functions.

The formation of regional offices or new agency units will have an influence on the Regional Government apparatus, where the number of apparatuses will increase with the number and magnitude of regional service institutions established so that regional autonomy will backfire if not accompanied by proper preparation. Local governments will experience difficulties if the ability of its officials is inadequate.

The handing over of functions and authorities, especially the handing over of personnel affairs to there gions so that a massive addition or transfer of the apparatus tot he regional government body will have animpact on the development of the apparatus starting from entry toretirement. In the local government environment, the role of employees both in dividually and in groups is very important and decisive. HR as anassetand the main element in anorganization plays a very decisiverole in achieving organizational goals (Ikhsan, 2016).

All element so forganizational resources will not function without being handled by humans who are the main drivers of the running of the organization (Idris \&Konadi, 2012). In each activity must be timely and acceptable according to the work plan set or in other words have a high effectiveness and performance. Without good or high performance from the 
apparatusitis difficult for anorganization in the process of achieving its goals. As statedby Steers (1985) that without good performance at all level soft heorganization, the achievement of goals and or ganizational success becomes something that is very difficult and evenim possible.

So that local government officials are ableto show optimal performance while dismissing negative impressions about the government apparatus so far, the ability of the apparatus needs to be constantly improved, especially in organizing government and implementing development. The pre requisites for creating the ideal apparatus resources are those who are knowledge able, professional, responsible, far-sighted, highly disciplined, highly dedicated, creative and innovative (Idris, 2015).

The Government of the Regency of KutaiKartanegara as an agency that handles various activities of carrying out government, development and local community services, is required to have administrative technical and managerial technical skills. In implementing autonomy, regulating and managing affairs that are the responsibility of the region, it must be supported by apparatus resources both in quality and quantity. One of the serious obstacles faced by the West Kutai Regency Government in the implementation of government and development and the provision of services to the community is the lack of human resources in this case skilled and educated human resources in various fields, lack of skilled local government apparatus in handle the tasks assigned to him, and conditions of administrative capacity of employees that are inadequate so that many development efforts fail.

Development is the main tool for adjusting tasks and work with the abilities, skills and abilities and expertise of each employee (Noe et al., 2017). Development is also a factor that must be carried out in the administration of modern staffing and is an effort to improve employee performance to be more capable, skilled and clearly understand the tasks that must be done in accordance with his position as an administrator (Chen et al., 2004).

Human resource development programs that are implemented in the form of development, off and on the job, for example, are not carried out properly and are impressed by merely spending the available budget, as a result it can be suspected that increasing skills, knowledge and abilities as the main objectives that must be achieved becomes distorted (Swanson et al., 2001).

Policy preparation of apparatus resources that have performance will berelated to the type and nature of development that will be carried out to meet the needs of qualified personnel. In this case, it is necessary to pay attention to the needs of regional government organizations for specialists and generalists who are the executors or the spearhead of the administration and development. Employee performance is more directed at the level of employee performance. Employee performance reflect show employees meet job requirements well. Performance is basically what employees do and don't do.

Managing performance should be done collaboratively and cooperatively between employees, managers and organizations. Performance managementis a way to preventpoor performance and how to work together to improve performance. More importantly, performance management means continuous two-way communication betweent he performance manager (supervisor ormanager) and staff members. The purpose of this study is to describe, and analyze as pectsrelated to theme thod of developing the Apparatus Resources in the West Kutai Regency Regional Secretariat Office and to describe, and analyze as pectsrelated to the Performance of the Regional Government sApparatus, West Kutai.

\section{METHODOLOGY}

This research uses descriptive research method with a qualitative approach and this research is not only limited to data collection and compilation but includes analysis and 
interpretation of data that has been collected and everything in this study is determined from the results of data collection that reflects the real situation on the ground. This research takes place in the West Kutai Regency, and the site is in the room of the West Kutai Regency Secretariat Office, which are 2 Assistants and 9 Sections. Based on the type of data needed, the data collection techniques used are indepth interviews, documentation and observation. In this study the data analysis used is the intractive model of analysis. In this model the researcher is engaged in three components, namely data reduction, data display, and concluding drawing.

\section{RESULTS AND DISCUSSION}

Human Resource Development must always be pursued continuously to improve the performance of the organization and maintain its existence. Development of Government Apparatus Resources in this case is every effort to improve the implementation of current and future work, by providing information, influencing attitudes or increasing skills.

Regional apparatuses as executors in the regions in carrying out their duties are required to be able to adjust to the development of the community in their environment. For this reason, the performance of the regional apparatus in serving needs to be improved and efforts to improve the performance of the apparatus in the Regional Secretariat of the West Kutai Regency are closely related to the development of the apparatus which includes knowledge, abilities and skills in completing tasks and a willingness to understand and respond to the aspirations of the community.

In principle, the tasks of the regional government apparatus serving the public interest in accordance with their respective fields of work are in line with the dynamics of community life and the implementation of regional autonomy, then the scope of the tasks of the Regional Government seems increasingly complex and crucial, thus requiring the Regional Government apparatus qualified, professional and has the mental apparatus that is reliable in the context of carrying out the tasks of government, development and society.

\section{Apparatus Development Mechanism}

Proper development requires systematic and contextual planning so that it can produce outputs that are as expected by the organization, leadership and employees who will be involved in the development program. Before carrying out a program of apparatus resource development there are several mechanisms that need to be considered, namely determining needs or needs analysis, determining goals or objectives, and evaluating the implementation of the program so that development is expected to be able to produce the type of ability and level of expertise in accordance with organizational needs.

Apparatus resource development practices are often related to organizational strategic objectives. Development programs organized by an organization are in great demand by employees to be able to participate in both those carried out within the organization and its activities carried out outside the organization, but the most important are the programs offered or implemented according to the material, objectives and the needs of the organization concerned. Analyzing development needs requires accurate information about the organization's needs, task needs, and individual employee needs.

Organizational needs related to improving the quality of the capabilities and expertise of employees through development, this development program must be related to the mission, goals and strategies of the organization so that through this analysis development objectives can be formulated. 
The task needs analysis involves the analysis of competencies, which are the abilities, knowledge, expertise and behaviors needed for the success of employees in carrying out their responsibilities and can identify in what way the employee needs to be developed. While the analysis of employee needs involves assessing the abilities, knowledge and skills possessed by employees so that it appears who needs to be developed and needs to be analyzed the gap between the capabilities, knowledge and expertise possessed by the apparatus with the ability, knowledge and expertise/skills of general good as well as the specific requirements of a position.

Development involves determining career employees in the future based on performance that has been shown both in the form of strength and weakness in carrying out the tasks for which it is responsible. When employee performance does not look as expected it needs to be analyzed the factors that cause it, whether due to the ability, knowledge and skills factors or because of the design factors of the position, work system, work atmosphere and others so that solutions need to be sought to maintain employee performance so that actualization and work motivation is maintained and protected from the possibility of decreasing individual and organizational effectiveness.

From the results of the needs analysis, the next mechanism can be determined what is the purpose of developing the apparatus resources, who should follow, what material is presented, and what methods are used. Development carried out by the Regional Secretariat of West Kutai Regency which is internal as well as development carried out outside the organization offered by another institution needs to be assessed whether it supports the organization's vision, mission and strategy and is beneficial to the apparatus and whether the method used is sufficiently valid for produce the expected abilities and expertise

Development goals are made as specific as possible, otherwise it will be difficult to assess whether the goals have been achieved or not and to help ensure that the program is given to the appropriate people. The purpose of development is viewed from the side of the apparatus, namely the desired changes such as increased knowledge, attitudes, skills, abilities and career development, while viewed from the side of organizational interests is the achievement of maximum organizational performance as a result of the development that occurs in the apparatus. The aim is to improve technical, theoretical, conceptual and moral abilities and experience of the apparatus in order to have good performance and be able to carry out more difficult tasks and responsibilities in achieving optimal results.

The next mechanism of apparatus resource development is to conduct an evaluation to obtain feedback for similar development programs or further developments. The development program must prepare the apparatus to manage their new skills and behavior in carrying out the task.

Development of apparatus resources will emerge at any time as a result of changes in community demands and competition that often arises fluctuatively. Front-line employees will always be dealing with people's behavior that tends to change from time to time, so in a situation like this, increasing the competency of apparatus resources that provide services to the community will determine their subsequent performance.

Development is not considered as a form of trust or habit but must be supported by a positive and realistic philosophy about how development takes a role in organizational success. The Regional Secretariat of the West Kutai Regency as an organization must have a clear view of development, if there will be no form of development that is careless, unplanned and careless and waste of time and cost, so that it seems only to spend the available budget, the consequences can it is thought that increasing skills, knowledge, and 
abilities as the main goal is blurred. As carried out by the West Regency Regional Government in the development of apparatus resources without regard to the mechanism or stages of development that only meet the demands of the development organization (education) where the program is actually less needed, on the contrary the technical nature of the program is a neglected priority.

\section{Development Method}

The task accomplished and carried out by the Regional Government, especially the Sumbawa Regency Regional Secretariat, is highly determined by the apparatus resources that have the ability. Knowledge and expertise or skills in handling various fields of duty. Capable apparatus is apparatus that has dimensions of ability and skills, where these dimensions will be greatly influenced by the development program that is followed by the apparatus. Dimensions of the ability possessed by the apparatus to be able to carry out tasks and jobs, while the performance of the apparatus in mastering and understanding the field of his duties.

The Regional Secretariat of West Kutai Regency in increasing the knowledge, abilities and skills of its apparatus is carried out through development programs and in its implementation uses the on the job method and the off the job method. The method of developing the workplace (on the job) is a method that is often implemented by local governments in order to increase the knowledge, abilities and skills of the apparatus because this method is considered the cheapest method that does not even require a fee. However, the application of this method is based on the results of field research that has been carried out by the Regional Secretariat of West Kutai Regency often getting negative reactions from employees both included in the program and those not involved.

Development of personnel resources carried out by the Regional Secretariat of West Kutai Regency in order to improve the ability, knowledge, and skills of the apparatus through the on the job method consisting of work rotation, internships, coaching, work instructions, special projects, and temporary assignments, according with the results of research that researchers have done in general has been able to improve the knowledge, abilities and skills of employees involved in the development program.

The method of developing apparatus resources that is carried out outside the workplace is by sending the apparatus to attend education and training organized by the Government or by tertiary institutions. Based on the results of the study that the apparatus education and training activities carried out by the Regional Government of West Kutai Regency is one of the off the job methods of developing the apparatus so that after completing their education and training they are more empowered in the sense of being able to carry out various existing affairs.

In the administration of government, the implementation of development and provision of services to the community in the context of regional autonomy requires adequate preparation and quality of the regional apparatus. The effort that needs to be taken by the Regional Secretariat of West Kutai Regency is soon to develop the quality of the apparatus resources, even though it requires a sizable allocation of funds.

Rotation or mutation in the Regional Secretariat of West Kutai Regency is something that must be done if the organization wants to develop by following the changing times which are marked by the development of science and technology. This rotation is very important whether it is a rotation between one part and another but still in the same level or rotated to a higher position in the form of promotion. Sometimes the ability, knowledge and skills of the apparatus to be rotated, especially those promoted to occupy certain positions are still insufficient, so additional development programs are needed. 
Based on field research, it was found several weaknesses in the apparatus development program that must be addressed immediately by the Regional Secretariat of the West Kutai Regency in an effort to improve the performance of the apparatus, including the utilization, utilization or follow-up of apparatus resources that have followed the development program is still relatively low, in the sense not utilized in accordance with the development program that he followed.

Placement of the apparatus that is not in accordance with the specialization or educational background they have. The sending or involving the apparatus in one of the development programs does not go through the mechanism or stages in the development, so that the development of the apparatus is carried out seemingly carelessly.

The weaknesses above greatly affect the smoothness in the development of existing apparatus resources. Some steps as a relatively good solution can be taken by the Regional Secretariat of the West Kutai Regency in the context of developing apparatus resources and at the same time to cover up existing weaknesses.

The Regional Secretariat of West Kutai Regency in making the apparatus development program development must be based on needs analysis namely organizational analysis, task analysis, and analysis of individual apparatus. The need for development arises when certain weaknesses can be overcome by carrying out development, and development must be assessed from three levels, namely the level of the organization, the level of work or tasks, and the level of individuals.

Before carrying out the development of the Regional Secretariat apparatus of the West Kutai Regency it is better to make a planning and design of a development program which is a design and implementation plan that includes the type of development, the type of education and training, the objectives to be achieved, the preparation of the budget and the determination of the implementation time so that the program can run with a directed and planned.

\section{Performance of the Regional Secretariat of West Kutai Regency}

The main emphasis of the apparatus resources is in terms of the ability and willingness to always move and move in accordance with the demands of the organization that is to complete the tasks and work that is its responsibility. If the apparatus resources are more capable and willing to carry out the task, of course the achievement of the results expected by the organization can be achieved well.

Psychologically, the ability of the apparatus consists of potential ability (IQ) and reality ability (knowledge + skill). This means that the apparatus has the potential ability above the average (IQ: 110-120) with adequate education for the position and skilled in doing daily work, then the apparatus will more easily achieve the expected performance. Therefore, the Government of West Kutai Regency must place the apparatus in jobs that are in accordance with their expertise. (the right man in the right place the right man on the right job).

The motivation of an apparatus does not merely want to get a certain position but more than just getting a position that is the apparatus has a strong desire to excel. The position obtained is just a simple measure that shows how well the work has been done.

One of the policies adopted by the Government of West Kutai Regency in terms of Apparatus Development as mentioned above is the need for job analysis. Job analysis that describes the tasks in the office, information derived from the job analysis is used to clearly define performance. Steps taken to improve the ability of employees must start from the clarity of duties and functions of each employee. For this reason job analysis is required. 
From the results of the analysis it can be seen the weaknesses of the apparatus in carrying out their duties so that the necessary development program can be prepared.

From the description above, it is clear that the existence of the human resources of the West Kutai Regency Government apparatus needs to get attention, especially in dealing with the implementation of regional autonomy today, especially in efforts to improve quality, performance and professionalism as well as having knowledge and skills . For this reason, apparatus empowerment is needed, among others in the form of education, training and development.

The demand from the community to get good service from the Regional Secretariat Apparatus of the West Kutai Regency is a phenomenon that is difficult to avoid, this phenomenon demands a better performance of the apparatus in providing the best service to the community.

The performance of the apparatus is not only demonstrated by the ability of operational technical services that are administrative services such as serving the maintenance of IMB, making birth certificates, exploration permits, permits to open the RMU and so forth, but also shown by their ability in formulating public policy for public police for mulation.

Through the development of apparatus resources, plans can be made for the improvement and development of skills, abilities and performance of the apparatus which will ultimately produce the best organizational achievements and productivity and the goal of employee development and development is how to make available human resources be empowered appropriately and successfully as well as possible. The ability to carry out tasks properly from the apparatus is a responsive step to the wishes of the community, if the demands of this community are not responded to properly it will cause turmoil in the demands of the community who can express their aspirations in various ways, such as demonstrations and so forth. Therefore the responsiveness of all apparatus to the demands of society must always be a priority. In line with the demands of regional autonomy, that the principle of the main objective of regional autonomy is to bring the government closer to the people it serves so that services to the community are better and community control to the government becomes stronger and more real.

Efforts to improve the performance of the apparatus through a development program are intended to improve the image of the apparatus which has recently been highlighted by the public. For this reason apparatuses who are capable, professional and have character and work culture are needed, highly motivated to serve the needs of people who tend to be more complex (Boikov, 2000;Nahruddin\& Tambajong,2017). With this condition of the apparatus, both directly and indirectly will increase public accountability, because the state apparatus is able to establish public policies that are more transparent and can be measured the level of success (performance) of these policies (Alexander, 2000).

The performance of the West Kutai Regency Regional Secretariat apparatus in general can be said to be quite good when viewed from the completion of a number of task fields that are completed, but in the context of the apparatus' capacity it is meant here is the ability a person has to be able to carry out a task or job. Performance in an organization will greatly affect the ability of a person in carrying out their duties, because it is through this performance that the records of the resulting and the function of a job or activity during a certain period of time can be known, both in terms of quantity, quality and in terms of timeliness (Merchant, 1982). Quantity is intended here regarding the amount that must be completed. Quality concerns the resulting quality problems, while the timeliness is conformity with a predetermined time (Martin, 1993). In this regard, the evaluation of performance is a form of approach to see the extent to which a person's ability has been able to carry out organizational tasks that have been carried out effectively and efficiently. In 
performance appraisal, the results should be linked to resources under their authority such as human resources, funds, facilities and infrastructure, work methods and other matters concerned.

\section{CONCLUSION}

Proper development requires systematic and contextual planning so as to produce outputs that are as expected by the organizations, leaders and employees involved in the development program. With the mechanism or stages so that the overall apparatus and organizational goals are achieved, the mechanism or stage is an analysis of the development needs, setting goals, implementing the program, and evaluating the implementation of development programs. The implementation of the development of the apparatus of the West Kutai Regency Regional Secretariat using the on the job and off the job methods has been carried out to the maximum in order to get qualified apparatus in terms of abilities, knowledge, skills or expertise as well as mental attitude so as to produce apparatus that has performance the good one. The method of apparatus development which has been applied by the Regional Secretariat of the West Kutai Regency so far and is considered effective in its implementation is the method of job rotation, apprenticeship, training, special projects, temporary assignment work instructions, and apparatus development through methods obtained at the level of general education and education and training, namely methods of group discussion, simulations, lectures, role playing and internal training courses.

\section{REFERENCES}

Alexander, F. K. 2000. The changing face of accountability: Monitoring and assessing institutional performance in higher education. The journal of higher education, 71(4), 411-431.

Boikov, V. E. 2000. The professional culture of the civil service. Sociological research, 39(1), 13-23.

Chen, T. Y., Chang, P. L., \& Yeh, C. W. 2004. A study of career needs, career development programs, job satisfaction and the turnover intentions of R\&D personnel. Career development international, 9(4), 424-437.

Idris, A. 2015. Analysis of Works Ability and Entrepreneurial Spirit to Service Quality of Government Officials in Banda Aceh. Academic Research International, 6(1), 115.

Idris, A.\&Konadi, W. 2012. Pengaruh Regulasi dan Ketersedia an AnggaranTerhadap Kinerja Pelayanan Aparatur SKPD dan Implikasinyapada Kualitas Pelayanan Publik di Provinsi Aceh. Jurnal Kebangsaan, 1(1).

Ikhsan, A. 2016. Analisis Pengaruh Budaya Organisasi dan Kepuasan Kerja Terhadap Kinerja Karyawan Non Dosen Pada Universitas Mercu Buana Jakarta. Jurnal Ilmiah Manajemen dan Bisnis Mercu Buana, 2(1).

Martin, L. L. 1993. Total quality management in human service organizations (Vol. 67). Sage.

Merchant, K. A. 1982. The control function of management. Sloan Management Review (Pre-1986), 23(4), 43.

Nahruddin, Z., \&Tambajong, H. 2017. The Behavior of Apparatus and Cultural Organization in Provision of Public Service in District Level. Scholars Journal of Arts, Humanities and Social Sciences, 5(7B):716-720. 
Noe, R. A., Hollenbeck, J. R., Gerhart, B., \& Wright, P. M. 2017. Human resource management: Gaining a competitive advantage. New York, NY: McGraw-Hill Education.

Steers, R. M. 1985. Efektivitas Organisasi Seri Manajemen. Erlangga, Jakarta.

Swanson, R. A., Holton, E., \& Holton, E. F. 2001. Foundations of human resource development. Berrett-Koehler Publishers.

Zott, C. 2003. Dynamic capabilities and the emergence of intra industry differential firm performance: insights from a simulation study. Strategic management journal, 24 (2), $97-125$. 